\title{
Dimensional stability of distances between posterior teeth in maxillary complete dentures
}

\section{Estabilidade dimensional de distâncias entre dentes posteriores em prótese total superior}

\author{
Rafael Leonardo Xediek Consani* \\ Marcelo Ferraz Mesquita** \\ Lourenço Correr-Sobrinho ${ }^{* * *}$ \\ Maurício Tanji****
}

\begin{abstract}
The aim of this study was to assess the displacement of posterior teeth in maxillary complete dentures stored in water at $37^{\circ} \mathrm{C}$. Twenty acrylic resin-based maxillary complete dentures were constructed with the anterior teeth arranged in normal overlap and the posterior teeth in Angle class I. Metallic pins were placed on the labial cusp of the first premolars (PM), and on the mesiolabial cusp of the second molars (M). The final acrylic resin pressing was made in a metallic flask with aid of the RS tension system, and polymerized in a moist-hot cycle at $74^{\circ} \mathrm{C}$ for 9 hours. The dentures were deflasked after cooling in their own polymerizing water or after cooling in polymerizing water plus bench storage for 3 hours, and stored in water at $37^{\circ} \mathrm{C}$ for periods of 7,30 , and 90 days. Following deflasking and after each storage period tested, the PM-PM (premolar to premolar), M-M (molar to molar), LPM-LM (left premolar to left molar), and RPM-RM (right premolar to right molar) distances were measured with an STM Olympus microscope, with an accuracy of $0.0005 \mathrm{~mm}$. Collected data were submitted to ANOVA and Tukey's test (5\%). There was no statistically significant difference for the PM-PM, M-M, and LPM-LM distances after all storage periods when the flask cooling methods were considered. With exception of the RPM-RM distance after the 30-days water plus bench storage period, the other distances remained statistically stable.
\end{abstract}

DESCRIPTORS: Denture, complete; Water storage; Tooth movement.

RESUMO: O propósito deste trabalho foi verificar a movimentação de dentes posteriores em prótese total superior armazenada em água a $37^{\circ} \mathrm{C}$. Vinte próteses totais superiores foram confeccionadas com resina acrílica, com os dentes anteriores em transpasse normal e os posteriores em Classe I de Angle. Pinos metálicos foram colocados na cúspide vestibular dos primeiros pré-molares (PM) e cúspide mésio-vestibular dos segundos molares (M). A prensagem final da resina acrílica foi feita em mufla metálica com auxilio do dispositivo RS de contensão e a polimerização em ciclo de água a $74^{\circ} \mathrm{C}$ durante 9 horas. As próteses foram demufladas após esfriamento em água de polimerização ou em água de polimerização mais armazenagem em bancada por 3 horas e armazenadas em água a $37^{\circ} \mathrm{C}$ pelos períodos de 7, 30 e 90 dias. Após demuflagem e após cada período de armazenagem em água, as distâncias PM-PM (pré-molar a pré-molar), M-M (molar a molar), PMD-MD (pré-molar direito a molar direito) e PME-ME (pré-molar esquerdo a molar esquerdo) foram medidas com microscópio Olympus STM, com precisão de $0,0005 \mathrm{~mm}$. Os dados coletados foram submetidos à análise de variância e ao teste de Tukey com significância de 5\%. Em todos os períodos de armazenagem, as distâncias PM-PM, M-M e PME-ME não apresentaram diferenças estatisticamente significativas quando as muflas foram esfriadas pelos dois métodos. Com exceção da distância PMD-MD no período de 30 dias de armazenagem em água mais bancada, as demais distâncias permaneceram sem diferença estatística significativa.

DESCRITORES: Prótese total; Armazenamento de água; Movimentação dentária.

\section{INTRODUCTION}

The dimensional inaccuracy of the denture base produced during denture fabricating procedures is probably the result of polymerization shrinkage of the acrylic resin, and may be partially compensated by water absorption ${ }^{3,15}$. However, the undesirable dis- tortion of the denture base during clinical service is due to dimensional changes that occur in the acrylic resin ${ }^{16}$, and may be caused by one of the following factors: sorption or loss of water by the resin base, release of stresses and flexure fatigue of the base ${ }^{21}$.

\footnotetext{
* Professor, Department of Prosthodontics; **Professor and Chairman, Department of Prosthodontics; ***Professor, Department of Restorative Dentistry - School of Dentistry of Piracicaba, State University of Campinas.

**** Associate Professor, Department of Dental Occlusion, Lins Dental School, Methodist University of Piracicaba.
} 
Consani RLX, Mesquita MF, Correr-Sobrinho L, Tanji M. Dimensional stability of distances between posterior teeth in maxillary complete dentures. Braz Oral Res 2006;20(3):241-6.

The increase in dimension of the acrylic resin after soaking in water is usually greater than the polymerization shrinkage ${ }^{18}$. Since base polymerization shrinkage is unavoidable, a certain lack of dimensional accuracy has been accepted as one of the disadvantages of the construction of complete dentures ${ }^{15}$.

According to the diffusion theory for assessing the quantitative aspects of the kinetics of water sorption, the diffusion coefficient governs the rate of water sorption and the time required to reach equilibrium, which is also proportional to specimen thickness ${ }^{13}$. This fact signifies that the denture should fit better after water sorption than immediately after processing, since the shape of the oral tissues remains the same $e^{3,21}$. Thus, good wetting characteristics of the denture base are important, since materials with different surface energies have varying wettabilities ${ }^{23}$.

Water sorption by the denture during clinical use is not large, and the resulting expansion partially compensates the polymerization shrinkage ${ }^{11}$. Thus, water equilibrium and consequent denture base dimensional stability is often attained ${ }^{17}$.

The dimensional changes of light-cured, heatcured, and self-cured denture base resins were different from each other when stored in distilled water at $37^{\circ} \mathrm{C}$ for 7 days $^{8}$. Conversely, the linear dimensional changes observed were similar in all resin brands after storage in water for 30, 60 and 90 days at $37^{\circ} \mathrm{C}$, and these changes were so small that they were not clinically detectable ${ }^{9}$.

Measurements made in dentures made with the continuous-injection technique after immersion in water at room temperature for 1-8 weeks demonstrated that the base dimensional change was reduced, whilst no influence was observed in tooth movement with the trial-pack technique. In addition, these dimensional changes were influenced by palate shape ${ }^{19}$.

Water saturation of both dry heat- and wet heat-processed dentures was observed to be relatively low, due to their high initial water content. Therefore, the linear expansion associated with water sorption did not entirely compensate for the processing shrinkage of dry and wet heat-processed dentures, and did not demonstrate statistically significant difference in the resulting shrinkage ${ }^{22}$.

The purpose of this study was to assess the relative dimensional stability of the distances between posterior teeth in maxillary dentures following storage for 7,30 , and 90 days at a temperature of $37^{\circ} \mathrm{C}$, when the flasks were closed with the RS system, and cooled in their own curing water or cooled in their own curing water and later bench stored for 3 hours.

\section{MATERIALS AND METHODS}

Twenty maxillary complete dentures were constructed from identical stone casts simulating an arch without irregularities in the alveolar ridge crest. Wax denture base-plates with a thickness of $2 \mathrm{~mm}$ were made on the respective casts, and the height of the occlusion wax-rims was $20 \mathrm{~mm}$ in the labial sulcus of the cast, and $10 \mathrm{~mm}$ in the second molar zone. The occlusal rim heights were determined according to the Trubyte Biotone acrylic teeth size (Dentsply, Petropolis, RJ, Brazil), model $3 \mathrm{P}, 32 \mathrm{~L}$, and 33 degrees for normal mesiodistal contacts. The upper stone cast was mounted on a Mondial 4000 semi-adjustable articulator (Bio-Art Dental Products, São Carlos, SP, Brazil). In order to accurately mount all dentures on the articulator, similar V-shaped notches were carved in the base of the maxillary casts.

The arrangement of the left anterior teeth initiated with the carved wax-rim to serve as a guide for the central and lateral incisors, and canine positions. The same procedure was employed in the right arch. The posterior teeth were arranged starting with the first premolar until the second molar. The same procedure was used in the right arch. The teeth arrangement settings for the interocclusal relationship were $1 \mathrm{~mm}$ of anterior vertical overlap and posterior teeth in Angle class I.

Metallic reference pins with $1 \mathrm{~mm}$ in diameter were placed in the incisal border of the labial cusp of the first premolars, and mesiolabial cusp of the second molars. The upper dentures were flasked conventionally in Herodent Soli-Rock dental stone (Vigodent, Rio de Janeiro, RJ, Brazil), using a traditional standard metallic flask (J. Safrany Metallurgy Co., São Paulo, Brazil). One hour after flasking, the waxed dentures were softened for 10 minutes in boiling water. The two halves of the flasks were separated, the wax was removed and the stone was cleaned with liquid detergent and boiling water solution. After bench cooling, one coat of Isolak sodium alginate (Clássico Dental Products, São Paulo, SP, Brazil) was used as isolating medium.

Heat-cured acrylic resin (Clássico Dental Products), based on polymethylmethacrylate, was prepared with a polymer:monomer ratio of $3: 1$ by volume, and the dough was flasked in the plastic stage. A polystyrene sheet was used as separating 
Consani RLX, Mesquita MF, Correr-Sobrinho L, Tanji M. Dimensional stability of distances between posterior teeth in maxillary complete dentures. Braz Oral Res 2006;20(3):241-6.

medium between gypsum and acrylic resin during the initial flask closure under a load of 850 kilograms-force (kgf). After the flask was opened, the polystyrene sheet was removed, and the acrylic resin excess was trimmed. After the final packing pressure of 1,250 kgf the flasks were positioned between the 2 plates of the RS system ${ }^{4}$. This assembly was comprised of 2 iron plates, each one of them with $150 \times 40 \times 8 \mathrm{~mm}$. A screw of $9 \mathrm{~mm}$ in diameter was soldered into each end of the lower plate; 2 corresponding holes with a cross-section diameter of $10 \mathrm{~mm}$ were present in the upper plate. During the definitive flask closure, the screws of the lower plate were fitted into the holes of the upper plate and, after hydraulic flask pressing, the screw-nuts were strongly tightened to the screws before press releasing. Conversely to the traditional spring clamp, this procedure maintains constant metal-to-metal contact on the flask halves after press releasing.

Twelve hours after the final flask closure, the acrylic resin was polymerized in a moist-hot cycle at $74^{\circ} \mathrm{C}$ for 9 hours. The polymerizing unit (Termotron Dental Products, Piracicaba, SP, Brazil) was programmed to raise the temperature to $74^{\circ} \mathrm{C}$ at 1 hour, and then maintain it at $74^{\circ} \mathrm{C}$ for 8 hours. After polymerizing, the flasks of Group 1 were cooled slowly in a water bath, whereas the Group 2 flasks were cooled in a water bath followed by bench storage for 3 hours. The dentures were then deflasked, polished, placed on their corresponding stone casts, and the PM-PM (premolar to premolar),

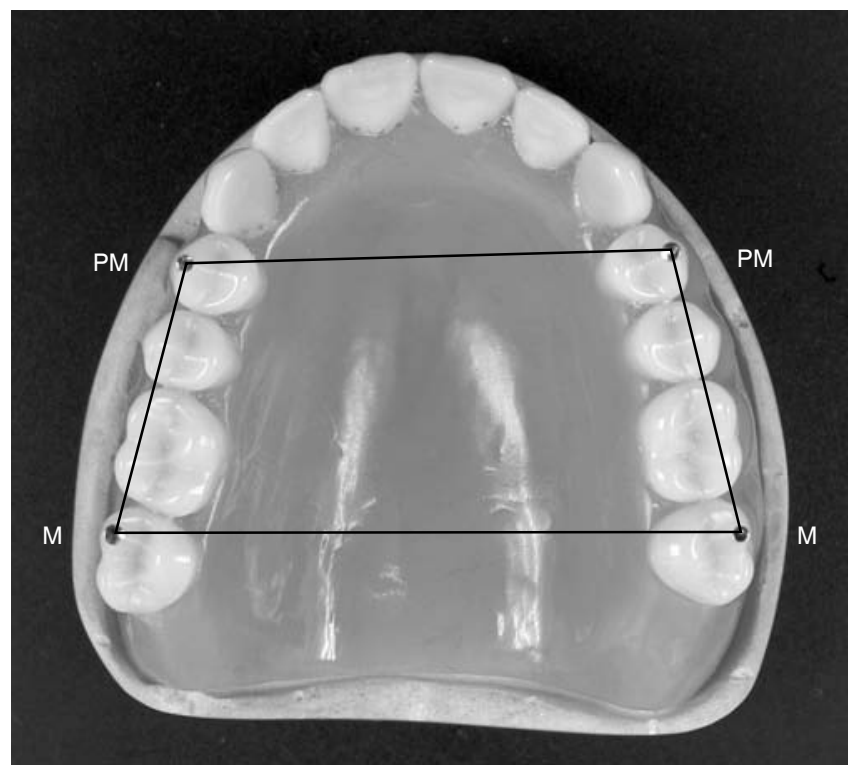

FIGURE 1 - Teeth distance measurements taken on dentures.
M-M (molar to molar), LPM-LM (left premolar to left molar), and RPM-RM (right premolar to right molar) distances (Figure 1) were measured with an STM microscope (Olympus Optical Co., Tokyo, Japan) with tolerance of $0.0005 \mathrm{~mm}$. Dentures were stored in water at $37^{\circ} \mathrm{C}$ for periods of 7,30 and 90 days. After each water storage period, the teeth distances were again measured in the same manner as performed for the deflasked period. Each denture was its own control. Data obtained were analyzed by two-way ANOVA and Tukey's test at a significance level of $5 \%$.

\section{RESULTS}

PM-PM (premolar to premolar), M-M (molar to molar), and LPM-LM (left premolar to left molar) teeth distances values were statistically similar $(p>0.05)$ at all periods when the flask cooling in polymerizing water was compared to the cooling in polymerizing water plus bench storage. Similar statistical results were observed among deflasking and water storage periods in each flask cooling methods (Tables 1, 2, and 3).

TABLE 1 - Means \pm standard deviations of the PM-PM distances $(\mathrm{mm})$ for deflasking and water storage periods, in relation to flask cooling factor.

\begin{tabular}{c|c|c}
\hline \hline \multirow{2}{*}{ Storage period } & \multicolumn{2}{|c}{ Flask cooling } \\
\cline { 2 - 3 } & Water & Water + bench \\
\hline Deflasking & $39.88 \pm 0.42 \mathrm{aA}$ & $39.85 \pm 0.51 \mathrm{aA}$ \\
\hline 7 days & $39.82 \pm 0.41 \mathrm{aA}$ & $39.81 \pm 0.58 \mathrm{aA}$ \\
\hline 30 days & $39.78 \pm 0.40 \mathrm{aA}$ & $39.83 \pm 0.52 \mathrm{aA}$ \\
\hline 90 days & $39.84 \pm 0.39 \mathrm{aA}$ & $39.93 \pm 0.54 \mathrm{aA}$ \\
\hline \hline
\end{tabular}

Means followed by same lowercase letters in the same column and same capital letters in the same row were not significantly different at the 95\% confidence level. PM: premolar.

TABLE 2 - Means \pm standard deviations of the M-M distances $(\mathrm{mm})$ for deflasking and water storage periods, in relation to flask cooling factor.

\begin{tabular}{c|c|c}
\hline \hline \multirow{2}{*}{ Storage period } & \multicolumn{2}{|c}{ Flask cooling } \\
\cline { 2 - 3 } & Water & Water + bench \\
\hline Deflasking & $53.15 \pm 0.57 \mathrm{aA}$ & $53.03 \pm 0.53 \mathrm{aA}$ \\
\hline 7 days & $53.07 \pm 0.52 \mathrm{aA}$ & $53.18 \pm 0.67 \mathrm{aA}$ \\
\hline 30 days & $52.97 \pm 0.43 \mathrm{aA}$ & $53.00 \pm 0.53 \mathrm{aA}$ \\
\hline 90 days & $53.01 \pm 0.44 \mathrm{aA}$ & $53.13 \pm 0.62 \mathrm{aA}$ \\
\hline \hline
\end{tabular}

Means followed by same lowercase letters in the same column and same capital letters in the same row were not significantly different at the $95 \%$ confidence level. M: molar. 
Consani RLX, Mesquita MF, Correr-Sobrinho L, Tanji M. Dimensional stability of distances between posterior teeth in maxillary complete dentures. Braz Oral Res 2006;20(3):241-6.

TABLE 3 - Means \pm standard deviations of the LPM-LM distances $(\mathrm{mm})$ for deflasking and water storage periods, in relation to flask cooling factor.

\begin{tabular}{c|c|c}
\hline \hline \multirow{2}{*}{ Storage period } & \multicolumn{2}{|c}{ Flask cooling } \\
\cline { 2 - 3 } & Water & Water + bench \\
\hline Deflasking & $20.21 \pm 0.60 \mathrm{aA}$ & $19.90 \pm 0.26 \mathrm{aA}$ \\
\hline 7 days & $20.06 \pm 0.41 \mathrm{aA}$ & $19.85 \pm 0.29 \mathrm{aA}$ \\
\hline 30 days & $19.78 \pm 0.55 \mathrm{aA}$ & $19.88 \pm 0.26 \mathrm{aA}$ \\
\hline 90 days & $19.84 \pm 0.56 \mathrm{aA}$ & $19.84 \pm 0.29 \mathrm{aA}$ \\
\hline \hline
\end{tabular}

Means followed by same lowercase letters in the same column and same capital letters in the same row were not significantly different at the 95\% confidence level. LPM: left premolar; LM: left molar.

Under the same conditions, with exception of the RPM-RM (right premolar to right molar) distance after the 30-days storage period for the polymerizing water plus bench storage, the other distances were not statistically different (Table 4).

\section{DISCUSSION}

Dimensional change of the acrylic resin is due to the entry of water among the polymethylmetacrylate molecules ${ }^{1,3}$, when absorbed during the polymerization or by immersion ${ }^{20}$ resulting in a plasticizing effect ${ }^{14}$.

Several studies have reported opposite or conflicting results, making the evaluation of the water absorption effect on teeth displacements difficult. It was demonstrated that the water sorption by the resin base during clinical use promotes dimensional changes, which alters the vertical dimension of the denture ${ }^{12}$. The expansion occurring in the vertical and horizontal planes after water sorption could cause changes in the occlusion due to teeth displacement $\mathrm{t}^{15}$. Although the change in the vertical dimension is considered clinically small, this may cause some discomfort to the patient.

Expansion was expected to occur when the deflasked denture was immersed in water because sorption by acrylic resin is a well-established event $^{3,13,23}$. However, this study showed dental displacement values for PM-PM, M-M, and LPM-LM distances after 7,30 , and 90 days with no statistically significant differences when compared to the deflasking periods in each flask cooling method. Similar statistical results were also found when these periods were compared between flask cooling methods (Tables 1, 2 and 3).

These results are consistent with those of a number of studies in the literature ${ }^{8,9,19}$. No signifi-
TABLE 4 - Means \pm standard deviations of the RPM-RM distances $(\mathrm{mm})$ for deflasking and water storage periods, in relation to flask cooling factor.

\begin{tabular}{c|c|c}
\hline \hline \multirow{2}{*}{ Storage period } & \multicolumn{2}{|c}{ Flask cooling } \\
\cline { 2 - 3 } & Water & Water + bench \\
\hline Deflasking & $20.76 \pm 0.75 \mathrm{aA}$ & $20.45 \pm 0.33 \mathrm{aA}$ \\
\hline 7 days & $20.87 \pm 0.66 \mathrm{aA}$ & $20.71 \pm 0.35 \mathrm{aA}$ \\
\hline 30 days & $20.96 \pm 0.66 \mathrm{aA}$ & $20.23 \pm 0.33 \mathrm{bA}$ \\
\hline 90 days & $20.89 \pm 0.78 \mathrm{aA}$ & $20.58 \pm 0.30 \mathrm{aA}$ \\
\hline \hline
\end{tabular}

Means followed by same lowercase letters in the same column and same capital letters in the same row were not significantly different at the 95\% confidence level. RPM: right premolar; RM: right molar.

cant difference was observed in the dimensional linear change when the acrylic resin was water stored for 90 days, probably due to the residual monomer, which impedes the sorption of water and maintains the dimensional stability of the denture base $^{9}$.

The cooling methods did not promote any significant effect on teeth displacement when the flask closure was performed with the RS pressure system. This result was not consistent with that of a study that demonstrated differences in the amount of water absorption by the denture base in relation to the different flask cooling methods. The greatest changes were observed in the dentures cooled by bench storage, and the smallest changes were seen in those cooled in their own polymerization water ${ }^{22}$.

Considering that the change promoted by both techniques was not statistically different, the additional flask cooling by bench storage for 3 hours was not sufficient to modify the dimensional conditions established by the cooling in the polymerizing water in relation to the released stress. Similar results were also observed in the displacement of teeth in the transverse and anteroposterior distances, when the dentures were invested in a metallic flask with the traditional acrylic resin pressure method, associating the water-cooling and bench storage methods ${ }^{7}$.

The dimensional stability of the teeth distances was probably due to the similar amount of water absorbed by mass volume, an occurrence also dependent upon the residual monomer amount present during the initial storage period. According to a previous study, there is a high amount of initial water in the dentures processed by the heating-water technique ${ }^{18}$. The initial amount of water probably decreased the saturation level of the denture 
Consani RLX, Mesquita MF, Correr-Sobrinho L, Tanji M. Dimensional stability of distances between posterior teeth in maxillary complete dentures. Braz Oral Res 2006;20(3):241-6.

during the initial storage in water causing similar stress release as a whole.

The stress released by the denture additionally bench-stored for 3 hours resulted in similar levels of teeth displacement when compared with the cooling in polymerization water alone. This result signifies that the delayed time in the bench storage had a similar effect on the dental displacement promoted by absorption in the initial period of water storage. These findings do not confirm results reported in the literature, relating that only water immersion for 60 days could compensate, in part, for polymerization shrinkage ${ }^{12}$.

With the exception of the RPM-RM distance after the 30-days storage period with water flask cooling plus bench storage, the other distances were not statistically different (Table 4). Thus, among four distance reference points, statistically significant difference was found only for the RPMRM distance. This exception influenced by the RS tension system is difficult to explain. As previously shown, the mesiodistal contact may maintain this distance unchanged ${ }^{11}$. Obviously, the RPM-RM distances were more influenced by the complexity of the involved stresses, acting as restrictive factors in the stability of the teeth distances, independently of the base contraction in the anteroposterior direction. A study on dental posterior displacement of complete dentures, processed with the traditional flask closure method, showed that the water absorption was not sufficient to cause significant changes in any transversely measured distance ${ }^{5}$.

\section{REFERENCES}

1. Anusavise KJ. Phillips' science of dental materials. Philadelphia: WB Saunders; 2003. 709 p.

2. Boscato N, Consani RLX, Consani S, Del Bel Cury AA. Effect of investment material and water immersion time on tooth movement in complete denture. Eur J Prosthodont Restor Dent 2005;13(4):164-9.

3. Campbell RL. Effects of water sorption on retention of acrylic resin denture bases. J Am Dent Assoc 1956;52(4):448-54.

4. Consani RLX, Domitti SS, Consani S. Effect of a new tension system, used in acrylic resin flasking, on the dimensional stability of denture bases. J Prosthet Dent 2002;88(3):285-9.

5. Consani RLX, Domitti SS, Consani S, Boscato N. Water storage effect on posterior teeth movement in maxillary complete dentures. RPG Rev Pós-Grad 2003;10(4):317-20.

6. Consani RLX, Mesquita MF, Consani S, Correr-Sobrinho L, Sousa-Neto MD. Effect of water storage on tooth displacement in maxillary complete dentures. Braz Dent $\mathrm{J}$ 2006;17(1):53-7.

7. Consani RLX, Mesquita MF, Sinhoreti MAC, Consani S. Influence of the deflasking delay time on the displacement of maxillary denture teeth. J Appl Oral Sci 2003;11(4):332-6.
Since the alterations in the transversal and sagittal sections of the posterior palatal region of the base were not able to affect the global teeth displacement, the true cause of this change remains complex, not uniform, and depends on the inner flask region ${ }^{10}$. The investment material is also an important factor to be regarded in denture processing. The association between gypsum or silicone and water storage did not alter the distances between teeth, except for the PM-PM distance after a 3-month water storage period with silicone investment ${ }^{2}$. Recent work had suggested that teeth displacement due to water immersion is also influenced by other factors such as base thickness, palate form, and difference in the stress releasing induced in different parts of the flask ${ }^{6}$.

It may be speculated that the difference observed in the RPM-RM distance would not be detected by the patients during clinical use. Further studies are necessary to investigate other methods that can yield minimal tooth displacement.

\section{CONCLUSIONS}

Within the limitations of the present study, the results showed that, with exception of the RPM-RM distance after a 30-days period with flask water cooling plus bench storage, the other distances were not influenced by the cooling methods when the flasks were closed with the RS tension system.

8. DaBreo EL, Herman P. A new method of measuring dimensional change. J Prosthet Dent 1991;65(5):718-22.

9. Dixon DL, Breeding LC, Ekstrand KG. Linear dimensional variability of three denture base resins after processing and in water storage. J Prosthet Dent 1992;68(1):196200.

10. Kawara M, Komiyama O, Kimoto S, Kobayashi N, Kobayashi K, Nemoto K. Distortion behavior of heat-activated acrylic denture-base resin in conventional and long, low-temperature processing methods. J Dent Res 1998;77(6):1446-53.

11. Lechner SK, Thomas GA. Changes caused by processing complete mandibular dentures. J Prosthet Dent 1994;72(6):606-13.

12. Mowery WE, Burns CL, Dickson G, Sweeney WT. Dimensional stability of denture base resins. J Am Dent Assoc 1958;57(3):345-53.

13. Ristic B, Carr L. Water sorption by denture acrylic resin and consequent changes in vertical dimension. J Prosthet Dent 1987;58(6):689-93.

14. Sadamori S, Ishii $\mathrm{T}$, Hamada $\mathrm{T}$. Influence of thickness on the linear dimensional change, warpage, and 
Consani RLX, Mesquita MF, Correr-Sobrinho L, Tanji M. Dimensional stability of distances between posterior teeth in maxillary complete dentures. Braz Oral Res 2006;20(3):241-6.

water uptake of a denture base resin. Int $\mathrm{J}$ Prosthodont 1997;10(1):35-43.

15. Skinner EW, Cooper EM. Physical properties of denture resins: Part I. Curing shrinkage and water sorption. J Am Dent Assoc 1943;30(6):1845-52.

16. Stebner CM. Report: Part II. An appraisal of recent significant developments in the practice of general dentistry. J Prosthet Dent 1957;7(6):828-32.

17. Sweeney WT. Acrylic resin in prosthetic dentistry. Dent Clin North Am 1958;2:593-602.

18. Sweeney WT, Paffenbarger GC, Bell JR. Acrylic resins for dentures. J Am Dent Assoc 1942;29:7-22.

19. Sykora O, Sutow EJ. Posterior palatal seal adaptation: influence of processing, palate shape and immersion. J Oral Rehabil 1993;20(1):19-31.
20. Teraoka F, Takahashi J. Controlled polymerization system for fabricating precise dentures. J Prosthet Dent 2000;83(5):514-20.

21. Woelfel JB, Paffenbarger GC. Dimensional changes occurring in artificial dentures. Int Dent J 1969;9:451-60.

22. Wong DMS, Cheng LYY, Chow TW, Clark RKF. Effect of processing method on the dimensional accuracy and water sorption of acrylic resin dentures. J Prosthet Dent 1999;81(3):300-4.

23. Zissis A, Yannikakis $\mathrm{S}$, Jagger RG, Waters MGJ. Wettability of denture materials. Quintessence Int 2001;32(6):457-62.

Received for publication on Jun 16, 2005

Sent for alterations on Mar 24, 2006

Accepted for publication on May 12, 2006 